Volume 2

Number 2 Popular Culture and Markets in

Turkey

2017

\title{
How Do Soap Operas Affect the Poor? Experiences of Turkish Women
}

Aras Ozgun

Izmir University of Economics

Dicle Yurdakul

Altinbas University

Deniz Atik

Izmir University of Economics

Follow this and additional works at: https://digitalcommons.uri.edu/mgdr

Part of the Anthropology Commons, Critical and Cultural Studies Commons, Marketing Commons, Mass Communication Commons, and the Sociology of Culture Commons

\section{Recommended Citation}

Ozgun, Aras; Yurdakul, Dicle; and Atik, Deniz (2017) "How Do Soap Operas Affect the Poor? Experiences of Turkish Women," Markets, Globalization \& Development Review. Vol. 2: No. 2, Article 2.

DOI: 10.23860/MGDR-2017-02-02-02

Available at: https://digitalcommons.uri.edu/mgdr/vol2/iss2/2

This Article is brought to you for free and open access by DigitalCommons@URI. It has been accepted for inclusion in Markets, Globalization \& Development Review by an authorized editor of DigitalCommons@URI. For more information, please contact digitalcommons-group@uri.edu. 


\section{Markets, Globalization \& Development Review}
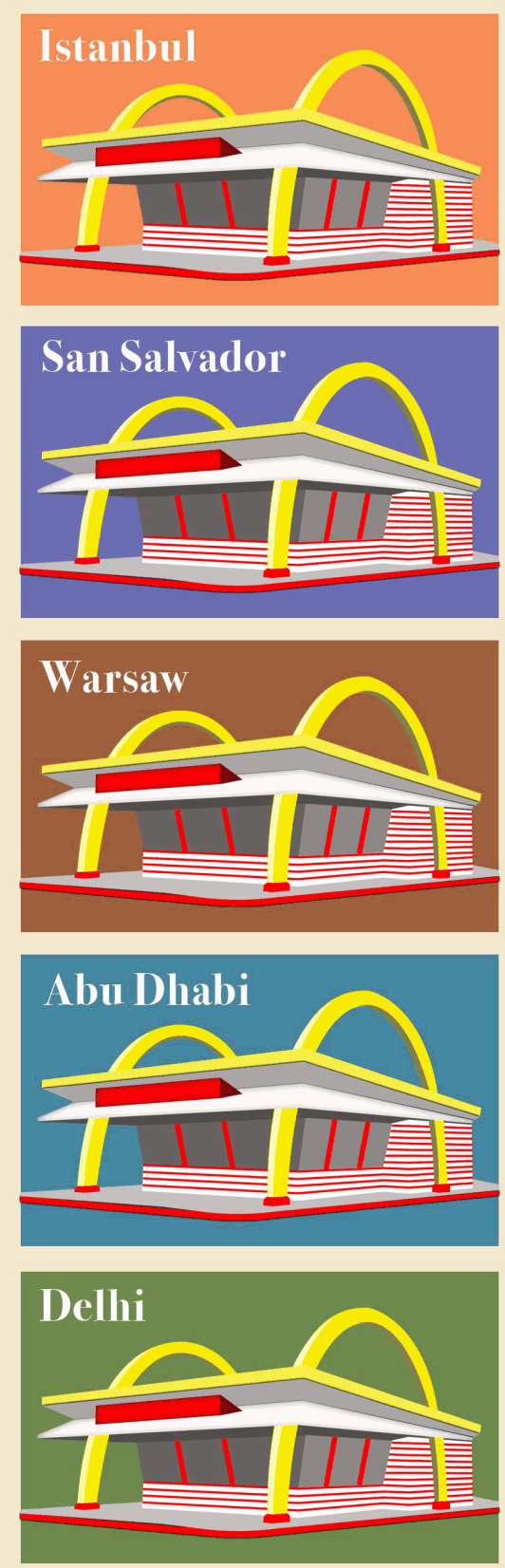
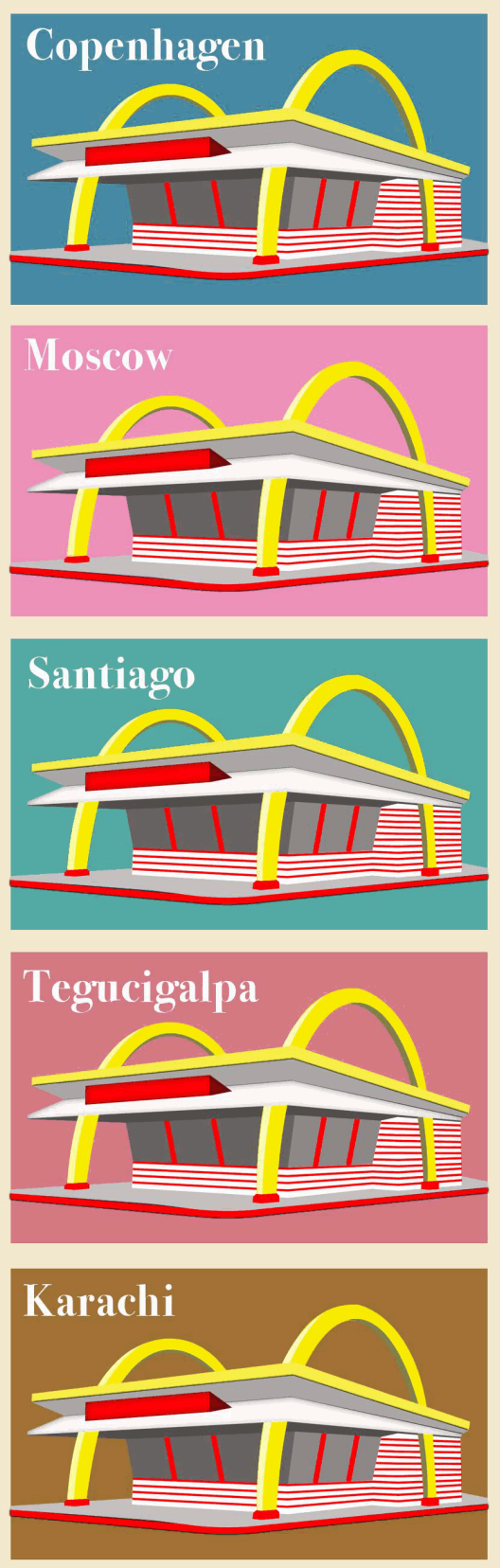
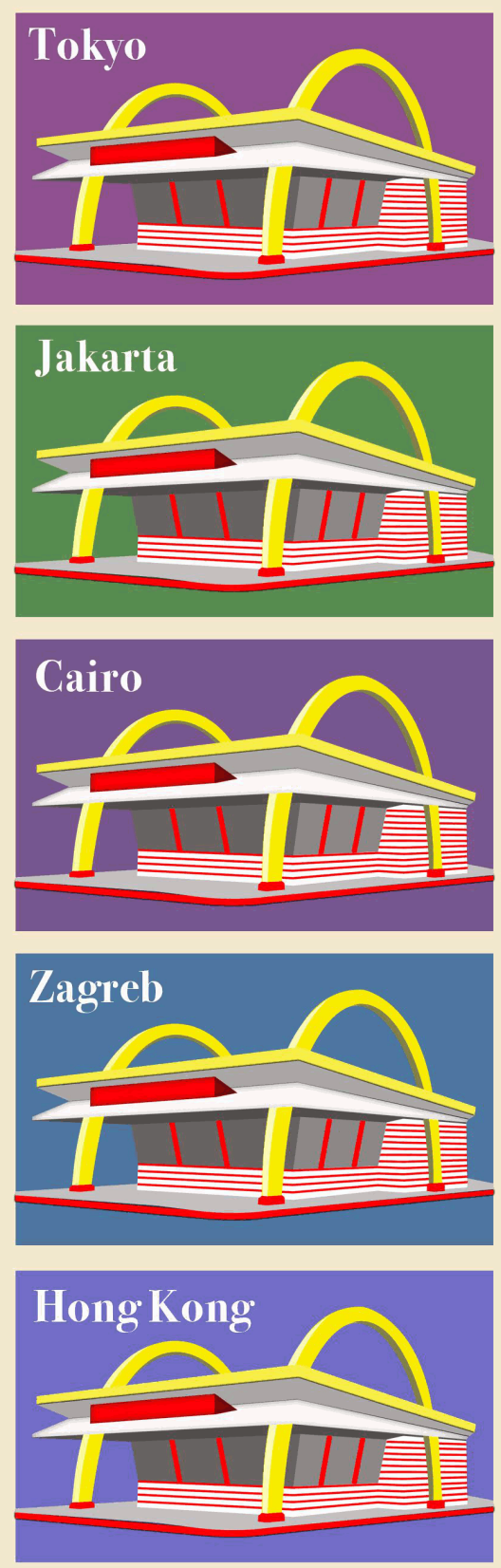

This article is available in Markets, Globalization \& Development Review: https://digitalcommons.uri.edu/mgdr/vol2/ 


\section{How Do Soap Operas Affect the Poor? Experiences of Turkish Women}

\section{Introduction}

Although the cultural aspects of poverty are well studied and documented in the fields of sociology, anthropology, and urban studies, it remains a relatively understudied subject in the disciplines of marketing and media studies. These two disciplines have been mainly concerned with reaching populations with a certain level of purchasing power. In fact, marketing and media industries are highly integrated because of the economic structuring of the profit oriented media sector, in which advertising revenues constitute the main income of the media outlets.

Our primary aim is to explore the effects of mass media on the lives of the poorest of the world's populations. This group, at the bottom of the pyramid, constitutes $70 \%$ of the world population (according to the poverty line of $\$ 8$ per day, in Purchasing Power Parity or PPP terms, see Worldbank PovCalNet 2013). The key areas of inquiry include the following: how do people in poverty relate to mass media, how do they incorporate media exposure into their everyday lives, and what do they do with media and what do media do to them?

For the purposes of this inquiry, we delineate the "exposure to media" as soap opera viewership since our study shows that this is the form of television programming to which the poor have the most contact. The poor, primarily women, are therefore the main subjects of our empirical study. Furthermore, we have chosen to conduct this inquiry in the country of Turkey as it presents an ideal place to situate this research because of the high poverty rates and the hegemonic policies that allow private channels to dominate broadcast media, whose commercial interests shape their choice of programming.

Traditionally, critical media and cultural studies have long described the negative effects of mass media in various social contexts. However, access to communication channels and exposure to media have been perceived as positive norms, at least in quantitative terms, when assessing the quality of life both in scholarly research and common parlance. We agree with Achrol and Kotler (2016) that "modern communication is essential and inevitable if the poor are to be lifted from the clutches of poverty, and if marketing is to be put in service of their aspirations" (p.28). We do tend to believe mass media enrich people's lives, inform them, connect them to the world, include them in public life, and make them aware of their own life as it relates to the world outside. 
The advertisement driven economic structuring of private media outlets is reflected in the content of their television programming in various ways. This is not only recognizable in the commercials that interrupt television shows, but also through subtler forms of advertising such as product placement, plot/character/story line development, etc. The underlying question that inspires this research is whether the exposure to media, in this case to soap operas, really enriches the lives of the poor, inform them, and include them in public life, or to the contrary, contribute to their poverty.

\section{The transition between the poor audience and the low-income consumer}

Previous research efforts in the field of audience studies (the section of media studies that is concerned with the ways in which media reaches and effects its audience) show us that the effects of media are not homogenous across society, and various social conditions and demographic variables (cultural background, income level, social status, age and gender) change peoples' relation to media (Ang 1991; Brunsdon 1986; Morley 1986). Ien Ang, following Morley's and Brunsdon's work, points out that male and female audiences' relations to television are shaped by complex "cultural and social arrangements" (Ang 1991, p. 42). Watching television remains a domestic, cultural activity. Morley's and Brunsdon's analyses show that, there are differences in the perception and reception of televisual texts that stem from the structuring of the domestic power relations. For example, the home is most commonly seen as a place of leisure for men who traditionally work outside of it. Watching television at home is a leisure activity for them. Thus, men's relationship with television is rather uninterrupted, concentrated and pleasure oriented. Whereas women, for whom the domestic space is also a place of work, experience television as either an activity that blends into their essential everyday reproductive/domestic labor processes, or in the form of keeping their husbands company while watching his choice of programs in the evening (Morley 1986, 1992). Thus, the difference between men's and women's exposure to media starts with their viewing experience, and extends to the type of narratives they are exposed to, and how they incorporate the results of such exposure into their ideological dispositions as well as their everyday practices.

Such differences become more profound among the low income communities that are the focus of this research. In these communities, a majority of the men earn a living by taking on low paying, manual jobs, or precarious labor positions in the service economy. Women, on the other 
hand, are occupied with their own childcare and other domestic labor processes, or perform domestic work outside of the home, such as home cleaning, etc.

Other studies show us that the effects of poverty are also gendered (e.g., Fukuda-Parr 1999; Gunduz-Hosgor and Smits 2008; Holt and Thompson 2004; Tarkowska 2002). The gendering of poverty is more evident in traditional communities where women have fewer educational opportunities that would allow them to pursue skilled work, and their social status (and thus their social mobility) is dependent on men. This means that, women are not only more financially dependent in low-income communities (i.e., they are restricted by their husbands' poverty), but also more socially vulnerable to the effects of poverty (i.e., there are no opportunities for them as individuals to lift themselves out of poverty). Thus, our focus in this research is on the most powerless of the poor: women.

Our empirical data, as well as previous studies (e.g., Ang 1991; Brunsdon 1986; Morley 1986), show us that women in low income communities are consumers of daytime television programming of which soap operas occupy a significant part. Because of their narrative structures, soap operas provide women with powerful devices for selfidentification and cultural perception among other cognitive, affective and ideological social processes. Thus, our research concerning the effects of mass media on poor women's social conditions refers specifically to the effects of soap operas, as this form of program constitutes the majority of their exposure to media.

Yet, departing from the fact we mentioned earlier - that soap operas are a part of the advertisement based media economy, their narrative contents, styles and formats are shaped by commercial interests, and supported by the empirical data that affirms soap operas as the primary connection of poor women to the outside world beyond their neighborhood - we will argue that, such exposure to media via soap operas also constitutes a major channel for poor women's exposure to consumer culture and marketing. In fact, the absence of other means of socialization, entertainment and cultural development (which may be available to other socioeconomic segments) amplifies the effects of such exposure.

According to O'Guinn and Shrum (1997), mental representations of the social world and perceptions of affluence are shaped during the socialization process on which television has a powerful influence. Providing consumers with images and lifestyles that are not part of their daily experiences, television programs offer a world of imagined affluence. 
Previous studies show that education and income are negatively correlated with the amount of television viewing (Condry 1989). Thus, watching TV is an affordable and low cost entertainment for less educated people with lower incomes (Gerbner et al. 1980). It may also provide a temporary feeling of escape from a reality that may otherwise induce feelings of alienation and incapability (Katz and Foulkes 1962). Mass media rarely show images and stories of low-income populations, as it aims for the attention of wealthier consumers (Lichter, Lichter and Rothman 1994). In spite of this discrepancy between the actual world and the affluent world of television, consumers do not question or reject these discrepancies in most cases. Instead they are in a passive state of engagement while watching TV (O'Guinn and Shrum 1997).

According to the cultivation theory, television significantly affects the construction (cultivation) of perceptions of reality (Gerbner et al. 1977). The theory states that constant viewers interpret the social world as consistent with the televised representations of it (O'Guinn and Shrum 1997). Higher levels of exposure to television lead to uniform social perceptions, interpretations and values (Gerbner et al. 1977; O'Guinn and Shrum 1997). This dynamic, or effect, in fact brings the low income audience to the attention of mass media. Not only does the lower income viewer constitute the target audience of mass consumption products, their exposure to media teaches them the social codes of consumer culture, mentally allowing them to be part of the market that they are economically excluded from. Consequently, even though they do not have the purchasing power to acquire high end consumer products, the viewers perceive themselves as more affluent "potential consumers".

The process of learning how to act as a "proper" consumer, as defined by the marketing institution (Atik and Firat 2013) occurs by consumer socialization. Ward (1974) defines this as "the processes by which young people acquire skills, knowledge and attitudes relevant to their functioning as consumers in the marketplace" (p.2). The consumer socialization agents, some of which are mass media, family and peers, help us to learn how to function as consumers through adopting the dominant consumption patterns and practices. These agents, in a sense, guide our way to be part of the consumer culture through teaching us the social significance of commodities and their contribution to our success in social roles and relationships (Ward 1974). In the context of this research, soap operas act as the consumer socialization agents for lower income women.

The images portrayed in media are often idealized representations, which lure the consumers towards identifying themselves with. Without 
questioning the factuality of these idealized images, consumers adopt the lifestyles associated with the representations (Hirschman and Thompson 1997). Although the patterns of consumption are communicated to a mass market, the effects of media vary between different groups due existing social stratification norms and the growing gap between high and low income populations (Tellefsen and Takada 1999). In the low income setting, being exposed to these idealized images that in fact lay beyond the reach of the individuals' financial means, can be a major source of dissatisfaction and trigger negative feelings (Belk and Pollay 1985). This biased perception about the welfare of others in society, and the following comparison with their own lives, may provoke various reactions ranging from dissatisfaction to class envy, and consequently raise poor people's expectations from life (O'Guinn and Shrum 1997). Our research indicates that such consumer socialization through soap operas eventually pays off, and turns "potential consumers" into real customers by influencing them to use their limited financial means for purchasing desirable consumer products, often neglecting the basic necessities of their lives.

In addition to the above discussions on the consequences of poverty in marketing and consumer research literatures, we also observe that such consequences can be felt even more deeply particularly by poor women. Therefore, we adopt a feminist perspective to understand women's struggle with poverty, hope to shed light on women's exposure to and exclusion from the market, the consequences of this exclusion, and their coping strategies.

\section{Methodology}

In our attempt to explore and understand how their media consumption affects the life experiences of women living in poverty, we do share methodological interests with the New Audience Research in media studies, which focuses on cultural forms that are marginalized by the hegemonic cultures and undermined by mainstream research interests. Similar to the interpretive turn in consumer research in the early 1980s (e.g., Anderson and Ozanne 1988), mass communication studies witnessed an increasing interest in qualitative audience studies at around the same time. 'New Audience Research' applies interpretive ethnography to media audiences (e.g., Corner 1991), in order to understand cultural practices - such as romance novel reading (e.g., Radway 1987) and television viewing (e.g., Morley 1989) - from the perspectives of those who are involved in them. New Audience Research's investigation of the pleasures and displeasures people extract from media in their domestic 
lives also exposes its feminist heritage, shedding light on how gender is constructed in practices of media consumption.

During 2011 and 2012, in light of these methodological approaches, we conducted 40, semi-structured in-depth interviews with low income women who were between the ages of 18 and 56, mostly elementary school graduates with no secondary education, and who lived in the poor neighborhoods of Izmir, Turkey. About a third of them did not have a job and relied completely on the limited income that their husbands brought home, barely enough for the basic necessities. According to GunduzHosgor and Smits (2008), the most important cultural factor that affects the gender roles and women's participation to work force in Turkey is the patriarchal ideology. The role of the breadwinner is still dominantly attributed to men (Holt and Thompson 2004) whereas the expected role of women in Turkish society is still that of the care giver. Even in the cases where our informants earned separate income, their jobs were undeclared and informal, with no insurance coverage. As a result of their lower level of education, poor women who had jobs outside have been primarily working in low paid positions that require few skills (Arslan and Kivrak 2004). In fact, the majority of our informants worked as part-time cleaners to help supplement the family budget. Regardless, this extra income still left them with no money to spare for their personal consumption (see Table 1 for more detailed information about our informants).

Conducting interviews with low income people in poor neighborhoods posed many challenges such as communication barriers due to sociocultural and educational differences between the researchers and the informants. We tried to remove these barriers through rigorous fieldwork that enabled us to more comprehensively understand the setting both culturally and socially. Spending time with the women in these neighborhoods, participating in their meetings, and having informal, friendly conversations helped to remove the communication barriers. One of the researchers had participated in the daily and weekly meetings (coffee/tea gatherings) of the women in the community, and often met them in their homes. Spending time with them created opportunities for fruitful observations regarding their everyday life experiences, which contributed significantly to our knowledge about the social structure and practices of the community. Drinking tea together and having informal dialogues about their lives, experiences and difficulties not only helped in developing rapport but also led to forming close relationships with the informants prior to the interviews. 
Table 1. Informants of the study

\begin{tabular}{|c|c|c|c|c|}
\hline \multicolumn{2}{|c|}{ Pseudonym Age } & Literacy & Occupation & Marital Status \\
\hline Derya & 18 & High School & Student & Single \\
\hline 2 Gülay & 18 & Middle School & Unemployed & Single \\
\hline 3 Nilay & 20 & High School & Unemployed & Married - Pregnant \\
\hline 4 Hayriye & 23 & Elementary School & Cleaner & Married w/o child \\
\hline 5 Sinem & 23 & High School & Cleaner & Divorced \\
\hline 6 Nurcan & 24 & Elementary School & Unemployed & Married with $1 \mathrm{chi}$ \\
\hline 7 Hatice & 25 & Elementary School & Unemployed & Married - Pregnant \\
\hline 8 Aysel & 25 & Elementary School & Unemployed & Married with 1 child \\
\hline 9 Ela & 25 & Elementary School & Cleaner & Single \\
\hline 10 Suzan & 27 & No Formal Education & Cleaner & Married with 2 children \\
\hline 11 Leyla & 27 & No Formal Education & Cleaner & Single \\
\hline 12Banu & 28 & Elementary School & Unemployed & Married with 1 child \\
\hline 13Fahriye & 28 & Elementary School & Cleaner & Married with 2 children \\
\hline 14Pelin & 28 & No Formal Education & Unemployed & Married w/o child \\
\hline 15Nisa & 28 & High School & Cleaner & Married w/o child \\
\hline 16 Selda & 30 & High School & Cleaner & Married w/o child \\
\hline 17Gül & 30 & Elementary School & Unemployed & Married with 2 children \\
\hline 18 Seda & 30 & High School & Clerk & Single \\
\hline 19Şeyma & 32 & Middle School & Clerk & Married with 3 children \\
\hline 20 Sena & 33 & High School & Cleaner & Married with 2 children \\
\hline 21 Berrin & 33 & No Formal Education & Cleaner & Married with 2 children \\
\hline 22Nilgün & 35 & Elementary School & Unemployed & Married with 2 children \\
\hline 23Ceylan & 35 & No Formal Education & Cleaner & Married with 4 children \\
\hline 24 Ayla & 35 & Elementary School & Waitress & Married with 2 children \\
\hline 25Tülay & 35 & Elementary School & Cleaner & Married with 1 child \\
\hline 26 Ayfer & 38 & Elementary School & Cleaner & Married with 1 child \\
\hline 27 Nuriye & 38 & Elementary School & Cleaner & Married with 2 children \\
\hline $28 \mathrm{Hale}$ & 40 & Elementary School & Unemployed & Married with 2 children \\
\hline 29 Yeliz & 40 & Elementary School & Cleaner & Married with 2 children \\
\hline 30 Büşra & 41 & Elementary School & Cleaner & Married with 2 children \\
\hline 31 Zehra & 42 & No Formal Education & Unemployed & Married with 2 children \\
\hline 32 Filiz & 42 & Elementary School & Waitress & Divorced w. 2 children \\
\hline 33Emine & 42 & Elementary School & Cleaner & Married with 3 children \\
\hline 34Gonca & 46 & Elementary School & Cleaner & Married with 2 childre \\
\hline 35Fatma & 47 & No Formal Education & Cleaner & Married with 3 children \\
\hline 36 Hayat & 49 & Elementary School & Cleaner & Married with 2 children \\
\hline 37 Meltem & 49 & Elementary School & Cleaner & Married with 2 children \\
\hline 8Canan & 50 & No Formal Educatio & Unemployed & w with 4 children \\
\hline 39Muhlise & 54 & No Formal Educati & & Married with 3 children \\
\hline 40Bellez & 56 & No Formal Education & Cleaner & Married with 2 children \\
\hline
\end{tabular}


In addition to the interview data, we recorded detailed written and visual field notes to develop a more comprehensive understanding of our informants. These were later used during the interpretation of the data. After all the interviews were completed, systematic coding was conducted as suggested in literature (Carson et al. 2001; Kvale 1996; Silverman 2005; Spiggle 1994). Nvivo 8 software was helpful in the initial coding stage to ensure flexibility and ease of storing and data processing (interviews, field notes, participant information). Rather than having preconceived hypothesis, we tried to construct codes and categories out of the data. The categorization started after the initial coding, without prescribing the data to any given category, with the aim of bringing out new emerging themes without leaving any deviant cases behind. In the selective coding stage (Carson et al. 2001), we made comparisons to discover the interplay within and between categories in order to reach the similarities and differences, consequently leading to higher levels of categories and themes.

The following section details major findings, highlighting the effects of exposure to soap operas for women in poverty.

\section{Findings}

\section{Exposure to Consumer Culture through Soap Operas}

Our research shows that the majority of the women we studied watch television intensively. Watching TV remains as one of the very few daily entertainment activities for unemployed women, whereas it becomes a dominant form of leisure activity in the evening for the working women.

I usually watch TV the entire day. I watch all the soap operas. In fact, I would have been lost if there was no TV. I like paparazzi shows, I like soap operas. For example, there was this soap opera called Doktorlar (Doctors), that I watched. I watched all of it, actually. Think about it, what can a person do at home, all alone? The housework gets done quickly - we are just two people at home and we don't have children. The housework takes one hour. Then, we start watching TV even though it bores me after a while (Hatice, 25).

Especially for unemployed women who mostly live within the 'invisible' borders of the neighborhood - and sometimes within the house - television serves as a window to the world outside. It is not only the cheapest form of entertainment, but also the most prominent tool of information gathering (of various forms and kinds), in the absence of other technological communication channels due to the low income context. 
Some informants told us that, even though spending all their time watching television does not seem to be the best thing to do, for them it is often the only way of being informed about the outside world, due to limited access to other media, or due to their illiteracy, which makes television an even more crucial source of information. Yet, some of the informants told us that they intentionally avoid more informative programs such as the news and discussion shows:

I hardly watch the news. I cannot watch it; I want to throw myself out of the house when I watch the news. I don't know, I feel depressed... Yesterday on the news, some people shot down a soldier again. I could not watch it. I said to myself: "You better not see these things." I have enough troubles in my life (Zehra, 42).

Watching television, especially the news, feels like an additional emotional burden on these women as they are already struggling with their own difficulties. This may be interpreted as a form of emotional selfdefense and escapism. Even if such emotional defense mechanisms may be temporarily effective, in the long run it creates a barrier for accessing critical information that is rare and valuable considering their economic circumstances.

Our findings show that a majority of the women's time is spent on watching soap operas. Therefore, within the content of this study, we dare to assume that soap operas become their primary connection with the world outside their neighborhood as well as the principal mediatic agents in terms of their exposure to consumer culture and marketing. Thus, we specifically focus on the effects and outcomes of soap opera viewing on their experiences.

\section{Identification and Catharsis}

Watching television, specifically soap operas, gives the poor the opportunity to connect with their emotional states, from time to time, providing them with a feeling of catharsis. Our informants revealed that they identify with the characters of the soap opera because they themselves have had similar life experiences, and they derive emotional satisfaction and pleasure through the identification process. According to the interviews, some participants identified the evil character with their husbands, and some identified themselves with the protagonists of the soap operas. Fatma, for instance, pointed to the connection between her life and the poignant tale of a family in one of her favorite soap operas, in which the family migrates to Istanbul from a little town in Anatolia and face serious economic and social challenges: 
I don't know... They are like us, Eastern people. I feel close to them. Sometimes they show their homesickness... I really love that soap opera; I don't miss a single episode. Now it is over, but sometimes they show it during the day. I watch it sometimes for the second time - for example while I work. I like the father most, he is a nice person, and he struggles a lot. I don't know why, but I really like them (Fatma, 47).

Fatma and her family migrated from Ağrı (a province in Eastern Turkey) to Izmir 36 years ago. Yet, she often stated her homesickness and her desire to go back to her village during the interview. Her longing for her hometown and the difficulties she has experienced in the big city makes her identify with the characters, and she admits that watching the show brings forward deep emotional reactions from her. She says she is at times brought to tears because the programs rekindle nostalgia for her past, prompting her review and assess her current life conditions in comparison.

\section{Providing the Audience with What They Lack}

The interviews show that, although the participants derive parallelisms between themselves and the lives portrayed in the soap operas, which leads to their identification with the protagonists as we mention above, these serials also affect them by showing (and at times, through such identification process, emotionally fulfilling) what they lack in their everyday life - such as love, friendship, excitement, and power.

I love this soap opera, you know, Yer Gök Aşk (Love is Everywhere is a soap opera built on the story of two lovers who cannot unite because they come from different social classes). How can I tell you...? Well, frankly, I love it when it [the story] is about love... It is really so hard to find that kind of intense love... There is no such love nowadays... That's why I love it so much (Nurcan, 24).

For Nurcan, the most appealing aspect of the soap operas is the stories of love. She married a man she loved despite her family's disapproval. Due to the hard life and working conditions, however, as she recounts, her husband's romantic interest declined over time, and she started to feel disappointed. The idealized love affairs portrayed in the soap operas seem to trigger her disappointment further on the one hand, yet leave her with a feeling of satisfaction on the other by providing her with a representation of what she lacks in her life. Apparently, it is this romantic thrill - derived simultaneously from the pain and the pleasure of 
watching somebody else's romantic affairs - that keeps her watching these soap operas.

In this one (the soap opera named Doktorlar - The Doctors), the friends are so attached to each other; they do everything for each other. I wish I had those kinds of friends. But my friends are not attached to me at all. They even despise me... as my husband collects scrap... Some of my old friends even told me not to go to their houses anymore. That's t why I left them. My husband is more important than my friends... I have always wanted to be a doctor. Maybe that's why I am so affected by those doctor characters. For example, in the soap opera, when they rush to the emergency room, check the patients there, cure them... Do surgery... That's what I like in that soap opera (Fahriye, 28).

In Fahriye's case, soap operas fill a void: the lack of friendships and the career she desires. The shows serve as a way for her to temporarily identify with what is unattainable - prosperity, success and satisfying personal relationships. Her emotional responses during her viewing experience, such as laughing out loud or crying, display the level of her identification with the characters in the show. A vast literature in audience research tells us that, depending on their personal history, cultural background and other factors, different audience members can interpret the media texts differently, find different clues for identification processes, and derive different connections of pleasure and pain in their viewing experiences. Although the thematic repertoire of soap operas as a format may be limited, the richness of characters, stories and plot twists that distinguish the genre make soap operas available to a variety of decoding and interpretation processes at the same time; and as a result, make them appealing to a wide range of social subjectivities.

In addition to desires related with social status (such as having satisfactory romantic and friendship relationships or a good career), soap operas also trigger desires towards consumer goods or lifestyle consumption which may lead to severe consequences, considering the low income status of the audience concerned.

\section{Exposure to the Affluent 'Other Life'}

As discussed in previous studies, the entertainment media primarily portrays representations of the rich minority and their desirable lives rather than representing middle class and low income individuals who constitute the majority of the population (O'Guinn and Shrum 1997; Lichter, Lichter and Rothman 1994). As such, entertainment programs such as soap operas provide low income people with the excitement and joy of 
glimpsing into (albeit fictionally) 'the other life'. Yet, the great contradiction between these idealized representations of 'other lives' and their own reality raises questions in poor women's minds:

Look how those people are living! I sometimes ask my husband whether we'll ever have that kind of a life. My husband replies that it is not real, it is a fiction. He says that they play their roles and leave. But he says "don't mind that, maybe you'll have such a house one day." He says that, if it's God's will, he may be able to buy me a house as nice as that (Hatice, 25).

I sometimes ask myself if this kind of lifestyle truly exists in the world. We sometimes talk with my friends. Are there people really living this kind of life, so comfortable and carefree? They go to stores and buy whatever they want, without even asking the price! Pack this and this and that... Send this to my address... Is there really such a thing? When I watch it, I think as if it is a dream. You look at their houses; they have servants who take care of everything. They bring breakfast to their bedrooms. It makes one think, do such lives really exist? (Banu, 28)

For many of our informants such as Hatice and Banu, it is hard to believe that people can have such affluent and comfortable lives. Their encounter with 'the other life' triggers surprise and curiosity, and in many cases, leads to negative feelings, such as dissatisfaction and anger towards with their own circumstances. More importantly, through the positive identification process we mention above, these encounters with soap operas generate desires for the commodities that establish the luxury of the 'other life' that they watch day in and day out. Once this exposure is compounded by the fact that they have limited experience with the larger world, which makes them believe that the affluent lives depicted in the soap operas may really exist, the effect of the soap opera on the viewer becomes even stronger:

Mini Cooper! It is like my childhood dream. I watched it on the first day it (the car) was launched. It has been so many years; I was literally a child at the time... I don't think that my desire for that car will fade away because I have been thinking about it for so long. Do you know, it was the car of the blonde girl in Adını Feriha Koydum (a popular Turkish soap opera)! She had the red one! You stop for a moment and look at the car and think, "I wish I was the one driving that car." What would that change in the universe? Nothing, just me in the driver's seat (Nilay, 20). 
As a result, product placements in soap operas provoke the desire for these commodities not only among the people who can afford them, but also among those who cannot. The product placement in her favorite soap opera triggered Nilay's desire for a Mini Cooper, without neither acknowledging the product placement, nor questioning the possibility of attaining it. In some cases, repeated exposure to 'the other life' triggers not only a desire for the commodities associated with that lifestyle, but also dissatisfaction with lives in poverty. The urge to overcome such dissatisfaction sometimes amplifies low income people's challenges even further.

\section{Consequences of the Exposure to the Consumer Culture}

Desire is considered to be the the driving force behind consumption (Wilk 1997). The commodities that are not yet acquired are particularly considered as embodying certain meanings or happiness, and their absence creates a powerful urge to attain them (Belk, Ger and Askegaard 2003). In fact, one experiences discomfort if the absence is prolonged. Our findings show that, individuals living in poverty may adopt various behaviors to diminish the discomfort they associate by the lack of desired commodities:

I am not disappointed or sad. For example, I can wait until I have more money or I can force myself to work overtime for a whole week, and I can rent the car that I desire (Mini Cooper) at least for two days, and then I will satisfy my desire. I can reach it somehow. But just dreaming about it is, I don't know... Accepting that you cannot reach is much harder for me. Dreaming is good enough; you know that your dream will stay inside you forever. I like that hope, that way of thinking (Nilay, 20).

I wanted to have a cell phone; I desired it a lot... And I decided to do whatever I can to buy it. But I couldn't buy it at the time I wanted to; I collected the money in four months. My dad supported me as well; he knew that I wanted one for a long time. I finally bought it; it was a Nokia, one of the latest models. It was beautiful! Those touch screen cell phones were novelties in the market at those times. It costed around 700-750 TL (about \$300 US). Now it's cheaper, but it was very expensive when it was first launched. It was much more than my monthly salary (Şeyma, 32).

Nilay's quote explains that her hope keeps her desires alive and makes her search for alternatives to reach. Even though she may not be able to possess the desired commodity, a temporary experience with her 
object of desire could provide her with a sense of happiness through 'a taste of the other life.' In addition to these strategies, participants who have side incomes mention that they can wait for a long time and save money to reach the desired object in order to overcome the pain of envy or not attaining it. As revealed by Şeyma, it is possible for some people to receive financial support from family, or save money to reach the object of desire, especially if they are not married, and thus, able to spend the money they earn on the desired products.

Low income consumers also try to reach the desired objects, either through investing all of their limited income or through increasing their credit card debt, in order to protect themselves from the frustration of not attaining it. One of the questions that remain is about how far a person will go and how far they will stretch their limits to attain the coveted item.

The triggered desire sometimes leads to getting into debt, specifically for luxury items such as designer clothing, cell phones, or jewelry. Some of the subjects claim that they try to stay away from borrowing money or using credit cards, concerned with accumulating an unmanageable amount of debt and interest. Yet, a majority of them still use such finance tools, since these are often the only way to buy the product of their desire.

We bought the LCD TV on debt. Each installment was 450 TL. Our furniture and other things, total cost was $13000 \mathrm{TL}$. We could not pay that $450 \mathrm{TL}$, then they added the interest on top of it, and the debt became bigger and bigger. Instead of paying $13000 \mathrm{TL}$, we paid 20000 in total. I was pregnant when the bank confiscated our house. I felt very bad. They told me that if they told the lawyers that the debtor's wife was pregnant and she fainted, they wouldn't take away our stuff. That happened two or three times. They were coming; I was crying and so on... But thank God, we managed to pay it all (Aysel, 21).

This quote clearly reveals the negative consequences of credit card debt. Considering their level of income, it is not possible for the poor to afford these commodities without using credit cards, or payment plans. Yet these finance tools create a false confidence on the spending capacity of the poor, and amplify their desire to consume, which may drive them to use these financial tools carelessly, ultimately dragging them into a debt spiral.

Stretching their means to attain such products to satisfy their desire, or to suppress their disappointment with deprivation, practically means for the poor to divert financial resources that could otherwise be 
used to increase their quality of life. At this point, it is important to note that, the means and resources diverted to satisfy the desire for commodities do not have to be tangible; working extra hours to earn money for a desired product simply means that there is less time to be spent on social activities, with family, or for self-improvement. Adopting the consumption patterns of those with more disposable income does not increase the quality of poor women's life even temporarily, but aggravates the conditions and effects of poverty.

In some cases, the symbolic value of such objects of desire take precedence over sustaining their livelihood, and they divert their already inadequate financial resources at the expense of basic necessities:

I remember, one day we had just $16 \mathrm{TL}$ in our hands. I asked my daughter to buy some food from Sevgi Yolu (a street in the neighborhood where small shops are located). Those pants with flower figures were popular those days. She had seen one of them in a store, and she bought one for $15 \mathrm{TL}$. She came back home with 1 TL and no food. I asked her "Where is the food?" My husband told me to calm down; he said that it was enough for him to see his daughter happy. But we had no food. We ate whatever we had at home. I baked the old pieces of bread first. I made a soup and put those pieces of bread into it. That was our dinner that night (Fahriye, 28).

This quote shows how it becomes possible to sacrifice the basic necessities for even fleeting objects of desire, such as a pair of pants that will probably go out of fashion shortly after the moment of satisfaction. In this case, the symbolic meanings embedded in the fashion item attracted Fahriye's daughter so intensely that she sacrificed her family's dinner to satisfy her desires.

Our research also revealed that, in some cases, recurrent failures in their attempts to obtain objects of desire result in hopelessness for women in poverty.

I don't have any goals. For example, my husband talks about what he wants to do all the time: let's get retired and then move back to our hometown, buy a house there... I don't have any desires. I don't even name things like 'I want to have this or that'... I live in the day. If I am alive, that's enough. God knows what will happen tomorrow. I don't have a house, for example, I am renting. A long time ago, I hoped to buy a house, but it didn't happen. I don't care if I reach my dreams or not anymore. Since I don't have any hope for reaching those things, I don't want to dream and watch my dream 
fall apart. There are so many things to dream of otherwise (Nuriye, 38).

Feeling incapable of purchasing the desired item or to create positive change in their circumstances can lead to learned helplessness and adapting to deprivation (Hill and Stephens 1997), both of which can lead to a general pessimist outlook toward life. As argued, in the case of low income households, either state (being hopeful or hopeless about reaching the desired) may entail negative consequences. Sustained hopes for attending the desired commodity may direct low income consumers to push their limits financially through debt, and credit cards, that often leads to a debt spiral, which is a severe and common problem that faces those in a lower income bracket. On the other hand, being hopeless about satisfying their desires trigger negative feelings and increase the psychological burden of living in low income conditions further.

\section{Discussion}

Our findings show that soap operas constitute a major point of access to media within the low income strata of Izmir's women. Being exposed to affluent lives, opulence, and branded products through the soap opera narratives trigger poor consumers' desires for commodities, and deepen the contradiction between their current living conditions and what they perceive as the life of others.

On one hand, the possibility of attaining the desired commodities may lead the poor to invent solutions. Some may devote their energy to working overtime while some may use financial tools such as bank credit or credit cards, which in most cases lead to the severe problem of out of control debt (Hamilton 2009). On the other hand, when the possibility of reaching the desired seems unlikely, hopelessness may lead to the development of negative feelings such as shame, alienation, anger, dissatisfaction, feelings of incapability and powerlessness. This in turn can eventually affect the lives of the poor not only at individual level, but also at the family and community levels (Blocker 2011; Hirschman and Thompson 1997; Richins 1991). To protect themselves from the consequences of higher levels of exposure, a majority of the women in our study revealed that they were trying to stay away from other kinds of social exposures (such as going out to public places and shopping malls), thus isolating them from mainstream society even further. This selfimposed alienation, which functions as a countermeasure to dealing with the feeling of disappointment with their circumstances, also limits their lives and social interactions. 
Furthermore, the narrative format and style of the soap operas provide low income women with methods of identification (also see Ang 1991), and shape their perception of the outside world while feeding them escapist entertainment. Thus, the relevancy of the narrative format to their educational, cultural and social context seems to be the key to their exposure and, as our informants attest, they have a difficult time relating to informationally focused programming and TV news. As we discussed at length above, however, soap-opera based media exposure does not empower the poor women, but on the contrary, amplifies the effects of poverty, and sustains their economic and social alienation, turning poverty into a vicious cycle.

We conclude that, the consequences of such media exposure stems from the commercial nature of the programs, rather than the soap opera format and style itself (which appears to be the only relevant form of television viewing for women in poverty). By 'commercial nature', we point to profit oriented private media channels that broadcast these programs for advertisement revenues, and various marketing institutions that design the narrative content of the programs as saturated with various types of consumption incentives. Without changing other basic parameters of their condition, such as education level and economic access, expecting the poor women to change the channel and watch more informative programming would not only be an empty proposal, but also leave them alone as responsible of their own conditions.

Broadcast media, however, have always been publicly regulated and perceived as open to public initiatives from their very beginning, and such regulations and public initiatives had always been structured according to the notion of 'public interest'. What we have to consider is, then, simply the relation between the public good and the reduction of poverty; if the media exposure of the women in poverty is limited to certain types of programming because of cultural, social and economic reasons, then this precious connection must be cultivated for empowering them, towards changing their condition positively by utilizing every possible public resource. Such investment of public resources may range from providing culturally accessible public programming with socially responsible and informative narrative content, to regulating the marketing elements and advertisement content of private channels more tightly. In this sense, our findings are in line with the recommendations of Karnani (2017) regarding the government's crucial role as provider of basic public services and regulator of the private ones in benefit of the less privileged segments and that of Achrol and Kotler (2017) emphasizing social marketing. 
In fact, such public concerns regarding media outreach for underprivileged social groups had been a part of larger scale economic and social policies in developed countries, particularly in Western European countries where we find lower poverty rates and strong public broadcasting traditions. In underdeveloped and developing countries like Turkey, though, particularly through the neoliberal policy initiatives that became dominant over the past few decades, mass media have been perceived as an economic field that should be left to the private sector (and perhaps controlled only in terms of ideological content). In our view, restudying the media as a public good, and developing relevant public policies for empowering the economically underprivileged through media outreach remains a vitally important task.

In order to provide evidential basis for such public interest oriented policy making, we need to understand the issue from the perspectives of the vulnerable. To be able to comprehend the dynamics of poverty and develop applicable long-term strategies, a bottom-up approach that encompasses the voice of the poor seems to be crucial. Therefore, we believe, further empirical research is needed at the intersection of audience studies and consumer research in the context of poverty. 


\section{References}

Achrol, Ravi and Philip Kotler (2017) "Extending the Marketing Dialog on Poverty," Markets, Globalization \& Development Review, 2 (1), Article 6.

Achrol, Ravi and Philip Kotler (2016), "Marketing's Lost Frontier: The Poor," Markets, Globalization \& Development Review, 1 (1), Article 3.

Anderson Hudson, Laurel and Julie L. Ozanne (1988), "Alternative Ways of Seeking Knowledge in Consumer Research," The Journal of Consumer Research, 14 (4), 508-21.

Ang, len (1991), Living Room Wars: Rethinking Media Audiences for a Postmodern World. New York and London: Routledge.

Arslan, Gökhan and Serkan Kivrak (2004), "The Lower Employment of Women in Turkish Construction Sector," Building and Environment, 39 (11), 1379-87.

Atik, Deniz and A. Fuat Firat (2013), "Fashion Creation and Diffusion: The Institution of Marketing," Journal of Marketing Management, 29 (78), 836-60.

Belk, Russell W. and Richard W. Pollay (1985), "Images of Ourselves: The Good Life in Twentieth Century Advertising," Journal of Consumer Research, 11 (4), 887-97.

Belk, Russell W., Güliz Ger and Soren Askegaard (2003), "The Fire of Desire: A Multisited Inquiry into Consumer Passion," Journal of Consumer Research, 30 (3), 326-51.

Blocker, Christopher P. (2011), "Deprivation of Desire: Exploring Consumer Desire with Low-Income Individuals Living in Poverty," presented at the Consumer Culture Theory Workshop, Northwestern University.

Brunsdon, Charlotte (1986), "Women Watching Television," MedieKultur, 2 (4), 100-12.

Carson, David, Audrey Gilmore, Chad Perry and Kjell Gronhaug (2001), Qualitative Marketing Research. London: Sage.

Condry, John C. (1989), The Psychology of Television. NJ: Erlbaum: Hillsdale. 
Corner, John (1991), "Meaning, Genre and Context" in Mass Media and Society, Michael Gurevitch and James Curran eds. London: Edward Arnold, 267-84.

Fukuda-Parr, Sakiko (1999), "What Does Feminization of Poverty Mean? It Isn't Just Lack of Income," Feminist Economics, 5 (2), 99-103.

Gerbner, George, Larry Gross, Michael F. Eleey, Marilyn Jackson- Beeck, Suzanne Jeffries- Fox and Nancy Signorielli (1977), "TV Violence Profile No.8," Journal of Communication, 27 (2), 171-80.

Gerbner, George, Larry Gross, Michael Morgan and Nancy Signorielli (1980), "The 'Mainstreaming' of America: Violence Profile No.11," Journal of Communication, 30 (3), 10-29.

Gunduz-Hosgor, Ayşe and Jeroen Smits (2008), "Variation in Labor Market Participation of Married Women in Turkey," Women Studies International Forum, 31 (2), 104-17.

Hamilton, Kathy (2009), "Those Left Behind: Inequality in Consumer Culture," Irish Marketing Review, 20 (2), 40-54.

Hill, Ronald Paul and Debra Lynn Stephens (1997), "Impoverished Consumers and Consumer Behavior: The Case of AFDC Mothers," Journal of Macromarketing, 17 (2), 32-48.

Hirschman, Elizabeth C. and Craig J. Thompson (1997), "Why Media Matter: Toward a Richer Understanding of Consumers' Relationships with Advertising and Mass Media," Journal of Advertising, 26 (1), 43-60.

Holt, Douglas B. and Craig J. Thompson (2004), "Man-of-Action Heroes: The Pursuit of Heroic Masculinity in Everyday Consumption," Journal of Consumer Research, 31 (2), 425-40.

Karnani, Aneel (2017), "Marketing and Poverty Alleviation: The Perspective of the Poor," Markets, Globalization \& Development Review, 2 (1), Article 5.

Katz, Elihu and David Foulkes (1962), "On the Use of the Mass Media as Escape: Clarification of a Concept," The Public Opinion Quarterly, 26 (3), 377-88.

Kvale, Steinar (1996), Interviews: An Introduction to Qualitative Research Interviewing. Thousand Oaks: Sage. 
Lichter, S. Robert, Linda S. Lichter and Stanley Rothman (1994), Prime Time: How TV Portrays American Culture. Washington, DC: Regnery.

Morley, David (1986), Family Television: Cultural Power and Domestic Leisure. London: Comedia/Routlege.

Morley, David (1989), "Changing Paradigms in Audience Studies" in Remote Control: Television, Audiences and Cultural Power, Ellen Seiter, Hans Borchers, Gabriele Kreutzner and Eva-Maria Warth eds. London and New York: Routledge, 16-43.

Morley, David (1992), Television, Audiences and Cultural Studies. London and New York: Routledge.

O'Guinn, Thomas C. and Lawrence J. Shrum (1997), "The Role of Television in the Construction of Consumer Reality," Journal of Consumer Research, 23 (4), 278-94.

Radway, Jenice (1987), "Reading the Romance. Women, Patriarchy and Popular Culture," London: Verso (originally published in 1984).

Richins, Marsha L. (1991), "Social Comparison and the Idealized Images of Advertising," Journal of Consumer Research, 18 (1), 71-83.

Silverman, David (2005), Doing Qualitative Research, 2nd ed. London: Sage.

Spiggle, Susan (1994), "Analysis and Interpretation of Qualitative Data in Consumer Research," Journal of Consumer Research, 21 (3), 491503.

Tarkowska, Elzbieta (2002), "Intra-Household Gender Inequality: Hidden Dimensions of Poverty among Polish Women," Communist and Post-Communist Studies, 35, 411-32.

Tellefsen, Thomas and Hirokazu Takkada (1999), "The Relationship between Mass Media Availability and the Multicountry Diffusion of Consumer Products," Journal of International Marketing, 7 (1), 77 96.

Ward, Scott (1974), "Consumer Socialization," Journal of Consumer Research, 1 (2), 1-14.

Wilk, Richard R. (1997), "A Critique of Desire: Distaste and Dislike in Consumer Behavior," Consumption, Markets and Culture, 1 (2), 175-96. 
Markets, Globalization \& Development Review, Vol. 2 [2017], No. 2, Art. 2

Worldbank PovCalNet (2013), "An online analysis tool for global poverty monitoring," (accessed June 7, 2017) [available at http://iresearch.worldbank.org/PovcalNet/povOnDemand.aspx] 